TECHNICAL TRANSACTIONS 8/2017

CZASOPISMO TECHNICZNE 8/2017

CIVIL ENGINEERING

DOI: $10.4467 / 2353737$ XCT.17.135.6886

\author{
Jakub Popławski (j.poplawski@doktoranci.pb.edu.pl) \\ Małgorzata Lelusz \\ Department of Construction Materials, Technology and Organization, Faculty of Civil \\ and Environmental Engineering, Bialystok University of Technology
}

\title{
UTILITY ASSESSMENT OF BIOMASS FLY-ASH FOR PRODUCTION
}

\section{OF CONCRETE PRODUCTS}

OCENA PRZYDATNOŚCI POPIOŁU LOTNEGO ZE SPALANIA

BIOMASY DO PRODUKCJI WYROBÓW BETONOWYCH

\begin{abstract}
International agreements oblige our state to develop ecological sources of energy, one of which is biomass. During its combustion fly-ashes are produced. Several studies have shown that they might be useful in concrete production. The article presents a comparison of biomass fly-ash and coal fly-ash influence on the properties of cement composites. The replacement levels of cement by fly-ash (FA) were 20\%, $40 \%$ and $60 \%$. Biomass fly-ash FA(B) have replaced coal fly-ash by $0 \%, 50 \%$ and $100 \%$. The compressive strength tests showed similarities in strength development of coal and biomass fly-ashes concretes. Specimens with biomass fly-ash presented similar or better abrasion resistance comparing to coal fly-ash samples.
\end{abstract}

Keywords: biomass fly-ash, cement, concrete

\section{Streszczenie}

Zobowiązania międzynarodowe obligują nasz kraj do produkcji energii z wykorzystaniem jej odnawialnych źródel, jednym z nich jest biomasa. Podczas jej spalania powstają popioły lotne. Przeprowadzone dotychczas badania sugerują, że produkcja wyrobów betonowych może stanowić skuteczny sposób ich wykorzystania. Celem artykułu jest porównanie wplywu popiołu lotnego ze spalania biomasy i spalania węgla. Popioły (FA) stanowily 20\%, 40\% lub 60\% masy spoiwa. Popiół lotny z biomasy FA(B) dozowany był w ilości 0\%, 50\% lub $100 \%$ masy popiołów. Wyniki badań wytrzymałość na ściskanie wykazały podobny rozwój wytrzymałości betonów. Próbki z dodatkiem popiołów z biomasy charakteryzowaly się zbliżoną lub większą odpornością na ścieranie od próbek z dodatkiem popiołów węglowych.

Słowa kluczowe: popioły lotne ze spalania biomasy, cement, beton 


\section{Introduction}

The industrial-scale burning of carbon-based fossil fuels started at the turn of the $20^{\text {th }} \mathrm{c}$. Nowadays, global coal production is estimated up to 7-8 billion $t /$ year. In 2015 Poland produced 72 million t of that resource [1]. In the last decades of the $20^{\text {th }} \mathrm{c}$. the awareness of global warming raised. The rise of the average temperature on Earth is a direct consequence of greenhouse gas emissions. One of these is carbon dioxide. Our economy produced 295.8 million $\mathrm{t}$ of $\mathrm{CO}_{2}[2]$. The cement industry is a significant source of carbon dioxide, its share of global emission is estimated at $7-8 \%$. A variety of solutions ought to be considered to minimize industry's carbon footprint. One of these is reduction of the amount of cement in cement composite mixes. Some additives can partly substitute cement in the mix. $\mathrm{V}$ category fly-ash, rich in glassy silica and alumina, is an example of a pozzolanic additive. $\mathrm{W}$ category fly-ash is also considered a hydraulic additive, due to the presence of $\mathrm{CaO}$. Both of them are a side-product of coal burning in combined heat and power plants. The utilization of fly-ash in cement composites raises the ecological value of the material [3]. The introduction of biomass fuel to Polish energy production began after its accession to the European Union. Since then the share of renewable sources in overall energy production has grown to the value of $11.25 \%$ in 2013, most of it derived from solid biomass firing. The dominant type of biomass in Poland is woody and herbal biomass from forest management and agricultural production. Further promotion of biomass fuels is planned in Ministry of Energy document "Energy policy of Poland until 2050" [4, 5]. The introduction of biomass fuels in power plants has created a new field of study in utilization of their combustion side-products. An insufficient amount of research prevents biomass fly-ash systematization in concrete standards $[3,6]$. Various biomass fly-ashes have considerable activity and pozzolanic properties just like coal fly-ash $[6,7]$.

The PN-EN 450-1 standard defines fly-ash as "fine powder of mainly spherical, glassy particles, derived from burning of pulverized coal with or without co-combustion materials, which has pozzolanic properties and consists essentially of $\mathrm{SiO}_{2}$ and $\mathrm{Al}_{2} \mathrm{O}_{3}$ ”. Their colour is mostly light or dark grey, are alkaline, and have fineness similar to cement. The main physical properties are related to the combustion method in the heat or power plant $[3,6]$. The biomass fly-ashes chemical composition varies with the source of combusted biomass. The combustion conditions and fuel influence the physical properties, the specific surface area, and loss on ignition percentage. Generally, the biomass fly-ashes have higher alkaline oxides and lower alumina percentages than coal fly-ashes $[3,6]$. As mentioned, the current standards PN-EN 450-1 and PN-EN 206-1 allow utilization of coal and coal co-combusted fly-ashes. Siliceous and calcareous fly-ashes can become cement components if they meet the PN-EN 197-1 requirements. Siliceous fly-ashes are the most common type of fly-ash used in the Polish cement and concrete industry $[3,8]$. The growing problem with biomass fly-ashes storage, and similarities in chemical composition between biomass fly-ashes and coal fly-ashes, are encouraging enough to research biomass fly-ash and its influence on cement composite properties. Some suitable ways of utilization in concrete technology have already been 
proposed or discussed in the literature, including: dry-cast concrete, lower-class road pavements, heavy-metals immobilization, and self-compacted concrete. Any of these must take into consideration the unique properties of this type of fly-ash [9-11].

The addition of rice husk fly-ash is one of the best known biomass fly-ashes. It has an irregular shape of particles, with a slightly higher specific surface area than cement. Its consequently significant amount of silica is accompanied by pozzolanic properties [12, 13]. However, the ability to enhance the mechanical properties is also influenced by the crystalline structure of the material which is more dependent on the combustion process [14]. The comparative study of the filler-effect of sand and pozzolanic properties of rice husk fly-ash of the same size has shown that the pozzolanic reaction of the latter can be considerably more influential on compressive strength from 14 up to 90 days from casting [15]. It was reported that the replacement of $20 \%$ cement with rice husk fly-ash in concrete can result in the compressive strength results similar to results of cement specimens. Also barley husk fly-ash can also exhibit pozzolanic properties due to high content of silica [16]. The rice husk fly-ash can improve chlorine ions penetration resistance [12]. Regarding their properties, wood and woody material fly-ash is a more inconsistent material than e.g. rice husk fly-ash. Currently, wood waste fly-ash is mainly used for soil improvements in agriculture. Wood fly-ash has a bulk density ranging from 2.1 to $2.6 \mathrm{~g} / \mathrm{cm}^{3}$. Its particles are irregular in shape and porous $[17,18]$. The $\mathrm{d}_{50}$ size is about $110-150 \mu \mathrm{m}$. The combustion temperature drastically influences the amount of unfired carbonate residue. A temperature of combustion above $1000^{\circ} \mathrm{C}$ significantly decreases the amount of carbonates and elevates the amount of quick lime in the chemical composition. After combustion in $750^{\circ} \mathrm{C}$ the LOI is $4.6-8.4 \%$. Also, with increasing combustion temperature the amount of alkaline metals declines. Despite the contaminants, the sum of silica, alumina and ferric compounds can be up to $60-80 \%$ [17]. Some elevated levels of chlorines and sulphates were detected in some Polish biomass fly-ashes [5]. Generally, the amount of hydration heat decreases with the addition of woody fly-ash in a similar manner like in coal fly-ash. However, the addition of woody fly-ash up to $20 \%$ of mass can result in a similar heat of hydration like in pure cement binder [19]. The wood waste fly-ash influences the setting time. It delays the initial and final setting time of the concrete mix $[20,21]$. The mechanical properties of cement composites can be enhanced with wood waste fly-ash with the replacement level up to $10 \%$ [19]. Other research suggests that a replacement of $25 \%$ of cement with wood waste fly-ash can result in similar compressive strength to coal fly ash up to 7 days from mixing which suggest a filler-effect [18]. An additional increase of strength between 28 day and 365 day compressive strength of concrete specimens was also reported [22], suggesting the presence of pozzolanic reaction. The addition of woody biomass fly-ash can reduce the workability of cement paste and increase its water demand. A similar effect was observed with fresh concrete samples. A 15\% replacement of cement with sawdust fly-ash in concrete binder can reduce the slump test result by $32 \%$. Other results suggest that an addition of $10 \%$ of woody fly-ash to the binder has no adverse effect on water demand of cement mortar $[19,23,24]$. Self-compacting mortars with addition of $10 \%$ of wood waste fly-ash can exhibit compressive strength higher than cement control mortars up to 90 days after 
mixing [25]. Incorporation of woody material and rice-husk fly-ashes can improve alkalisilica mitigation. Those types of fly-ashes were reported to enhance chlorine penetration resistance in replacements levels up to $25 \%$. The presence of wood fly-ash does not tend to change the freeze-thaw resistance [17]. Woody biomass fly-ash tend to have less heavy metals in their chemical composition than coal fly-ash and can present some potential in the process of immobilization [11].

The aim of this paper is to assess the utility of wood biomass fly-ash for cement composite production. The coal fly-ash was substituted with wood fly-ash in a blended binder. For comparison, cement control specimens were made. The experiment program consisted of compressive strength tests after 7,28 , and 90 days, a density and water absorption test, and an abrasion test of cement concrete. Workability test were performed on cement mortars. Hydration heat measurements in the first $48 \mathrm{hrs}$ after mixing of cement binders were also performed.

\section{Materials and test methods}

\subsection{Materials}

As a binder material a commercial CEM I 42,5R cement was used. The material conformed to the requirements of the PN-EN 197-1 standard. The wood biomass fly-ash was taken from fluidized bed combustion $\left(750^{\circ} \mathrm{C}\right)$ while the coal fly-ash was taken from conventional combustion $\left(1100-1200^{\circ} \mathrm{C}\right)$. Both fly-ashes came from the local combined heat and power plant. The silica content, loss on ignition and pozzolanic activity index of both fly-ashes are presented in Table 1 . The grain size distribution of both materials are presented in Table 2. Natural sand with a maximum aggregate diameter of $16 \mathrm{~mm}$ was used. Tap water was used in the mixing and curing.

Table 1. The properties of wood biomass fly-ash and coal fly-ash

\begin{tabular}{|c|c|c|c|}
\hline Property & $\begin{array}{c}\text { PN-EN 450-1 } \\
\text { requirements }\end{array}$ & $\begin{array}{c}\text { Wood biomass } \\
\text { fly-ash }\end{array}$ & $\begin{array}{c}\text { Coal } \\
\text { fly-ash }\end{array}$ \\
\hline $\mathrm{SiO}_{2}$ content & $\geq 25 \%$ & $52 \%$ & $63 \%$ \\
\hline Loss on ignition & $\leq 9 \%$ & $12 \%$ & $14 \%$ \\
\hline $\begin{array}{c}\text { Pozzolanic activity index after } \\
28 \text { days }\end{array}$ & $\geq 75 \%$ & $77.0 \%$ & $77.2 \%$ \\
\hline $\begin{array}{c}\text { Pozzolanic activity index after } \\
90 \text { days }\end{array}$ & $\geq 85 \%$ & $80.3 \%$ & $95.9 \%$ \\
\hline
\end{tabular}


Table 2. The grain size distribution of wood biomass fly-ash and coal fly-ash

\begin{tabular}{|c|c|c|c|c|c|c|c|}
\hline Fly-ash type & $\begin{array}{c}\mathbf{2 - 1} \\
\mathbf{m m} \\
{[\%]}\end{array}$ & $\begin{array}{c}\mathbf{1 - 0 , 5} \\
\mathbf{m m} \\
{[\%]}\end{array}$ & $\begin{array}{c}\mathbf{0 , 5} \\
\mathbf{0 , 2 5} \\
\mathbf{m m} \\
{[\%]}\end{array}$ & $\begin{array}{c}\mathbf{0 , 2 5 -} \\
\mathbf{0 , 1 2 5} \\
\mathbf{m m} \\
{[\%]}\end{array}$ & $\begin{array}{c}\mathbf{0 , 1 2 5}- \\
\mathbf{0 , 6 3} \\
\mathbf{m m} \\
{[\%]}\end{array}$ & $\begin{array}{c}\mathbf{0 , 6 3 -} \\
\mathbf{0 , 0 1} \\
\mathbf{m m} \\
{[\%]}\end{array}$ & $\begin{array}{c}<\mathbf{0 , 0 1} \\
\mathbf{m m} \\
{[\%]}\end{array}$ \\
\hline Coal fly-ash & 0.0 & 0.0 & 1.1 & 15.4 & 25.7 & 41.2 & 16.6 \\
\hline Wood biomass fly-ash & 0.3 & 0.2 & 0.4 & 6.7 & 11.2 & 45.4 & 35.8 \\
\hline
\end{tabular}

\subsection{Mixture composition and specimen preparation}

The fly-ash amount changed between series of specimen. The percentage of fly-ash (FA) - understood as the sum of both fly-ashes - in the binder mass was $20 \%, 40 \%$ or $60 \%$. The content of coal fly-ash replaced with biomass fly-ash (FA(B)) was $0 \%, 50 \%$ or $100 \%$ mass of FA. The proportions are presented in Table 3. The water to binder ratio (w/b) was 0.5 . The mass of the binder was the same in the series, $380 \mathrm{~kg} / \mathrm{m}^{3}$. Table 4 presents the mixture composition of concrete specimens. In the calorimetric tests binder samples were used. The binders had also w/b equal 0.5 .

Table 3. The content of fly-ash in the binder and the content of biomass fly-ash in fly-ash mass

\begin{tabular}{|c|c|c|}
\hline Series code & $\begin{array}{c}\text { Biomass fly-ash content in fly-ash mass } \\
\text { FA(B) [\%] }\end{array}$ & Fly-ash content (FA) [\%] \\
\hline FA(B) $0-20 \%$ & 0 & 20 \\
\hline FA(B) $0-40 \%$ & 0 & 40 \\
\hline FA(B) $0-60 \%$ & 0 & 60 \\
\hline FA(B) $50-20 \%$ & 50 & 20 \\
\hline FA(B) $50-40 \%$ & 50 & 40 \\
\hline FA(B) $50-60 \%$ & 50 & 60 \\
\hline FA(B) $100-20 \%$ & 100 & 20 \\
\hline FA(B) $100-40 \%$ & 100 & 40 \\
\hline FA(B) $100-60 \%$ & 100 & 60 \\
\hline CEM I & 0 & 0 \\
\hline
\end{tabular}

The concrete specimens were cast in $10 \times 10 \times 10 \mathrm{~cm}$ moulds and completely compacted by vibration. The specimens were stored in water at temperature of $20 \pm 2^{\circ} \mathrm{C}$ and cured until test time. They were tested for compressive test after 7, 28, and 90 days. The density, water absorption and abrasion tests were performed after 28 days. The number of concrete samples in each series destined for a single test was 3 . For the hydration heat measurements the binder sample was prepared before the test. A single binder sample was made for each series. 
The workability test was performed on fresh cement mortars. The control cement mix was prepared in accordance to the PN EN 196-1 standard. In the two series with the addition of flyashes $30 \%$ by binder mass was replaced with either biomass fly-ash or coal fly-ash respectively.

Table 4. The proportions of concrete mixtures

\begin{tabular}{|c|c|c|c|c|c|c|c|c|}
\hline \multirow{3}{*}{ Series code } & \multicolumn{8}{|c|}{ The proportions for $1 \mathrm{~m}^{3}$ of concrete mix $[\mathrm{kg}]$} \\
\hline & \multirow{2}{*}{ Cement } & \multirow{2}{*}{$\begin{array}{l}\text { Biomass } \\
\text { fly-ash }\end{array}$} & \multirow{2}{*}{$\begin{array}{l}\text { Coal } \\
\text { fly-ash }\end{array}$} & \multirow{2}{*}{ Sand } & \multicolumn{3}{|c|}{ Aggregate } & \multirow{2}{*}{ Water } \\
\hline & & & & & $2-4 \mathrm{~mm}$ & $4-8 \mathrm{~mm}$ & $8-16 \mathrm{~mm}$ & \\
\hline $\mathrm{FA}(\mathrm{B}) 0-20 \%$ & 304 & 0 & 76 & 590 & 220 & 220 & 780 & 190 \\
\hline $\mathrm{FA}(\mathrm{B}) 0-40 \%$ & 228 & 0 & 152 & 590 & 220 & 220 & 780 & 190 \\
\hline FA(B) $0-60 \%$ & 152 & 0 & 228 & 590 & 220 & 220 & 780 & 190 \\
\hline $\mathrm{FA}(\mathrm{B}) 50-20 \%$ & 304 & 38 & 38 & 590 & 220 & 220 & 780 & 190 \\
\hline $\mathrm{FA}(\mathrm{B}) 50-40 \%$ & 228 & 76 & 76 & 590 & 220 & 220 & 780 & 190 \\
\hline $\mathrm{FA}(\mathrm{B}) 50-60 \%$ & 152 & 114 & 114 & 590 & 220 & 220 & 780 & 190 \\
\hline $\mathrm{FA}(\mathrm{B}) 100-20 \%$ & 304 & 76 & 0 & 590 & 220 & 220 & 780 & 190 \\
\hline FA(B) $100-40 \%$ & 228 & 152 & 0 & 590 & 220 & 220 & 780 & 190 \\
\hline $\mathrm{FA}(\mathrm{B}) 100-60 \%$ & 152 & 228 & 0 & 590 & 220 & 220 & 780 & 190 \\
\hline CEM I & 380 & 0 & 0 & 590 & 220 & 220 & 780 & 190 \\
\hline
\end{tabular}

\subsection{Test methods}

The compressive strength tests were performed in accordance to the PN-EN 12390-3 standard. The abrasion test was performed using the Bohme test method in accordance with PN-EN 13892-3:2005. The water absorption was calculated as the percentage of absorbed water mass compared to the mass of a specimen dried to constant weight. The workability test was performed in accordance with PN-EN 1015-3 and was assessed by percentile change in water demand needed to achieve a slump test result similar to the control specimens. Three tests on fresh mortar were performed for each series. The $48 \mathrm{hr}$ long heat of hydration measurements were performed on a conductive calorimeter. The calorimeter enabled the heat of hydration from the moment of binder and water mixing to be measured [26].

\section{Test results and discussion}

\subsection{Results of hydration heat measurements}

The calorimetric measurement results for the binder series with addition of biomass flyash are presented in Figure 1. The addition of biomass fly-ash has caused a diminishment of hydration peak and has delayed it in time. The replacement of $60 \%$ of cement with biomass flyash resulted in a reduction of hydration peak by $53 \%$ and its delay by $1.5 \mathrm{hr}$. There is a visible and significant peak in the first minutes from mixing water with binder. 
With the growing replacement of coal fly-ash with biomass fly-ash the hydration peaks were bigger. Comparing the binders with $40 \%$ cement replaced with fly-ash, the binder with biomass fly-ash replacement was characterized with a higher hydration peak by $20 \%$ (Fig. 2). The growing addition of biomass fly-ash caused a delay in its occurrence.

The biomass and coal fly-ashes significantly diminished the peak of hydration. The coal fly-ashes generally have a similar effect [3]. The differences in outcomes between the fly-ashes might have been the result of different chemical composition. The grain size distribution also could have been influential. The biomass fly-ash has the grain size distribution shifted towards smaller particles and those can provide an additional surface for the seeding of the hydration process. The decrease in the peak of hydration of the $20 \%$ replacement of cement with biomass fly-ash is comparable with the result reported [19] - contrary to the results observed in this study, the addition of woody biomass fly-ash slightly increased the hydration speed.

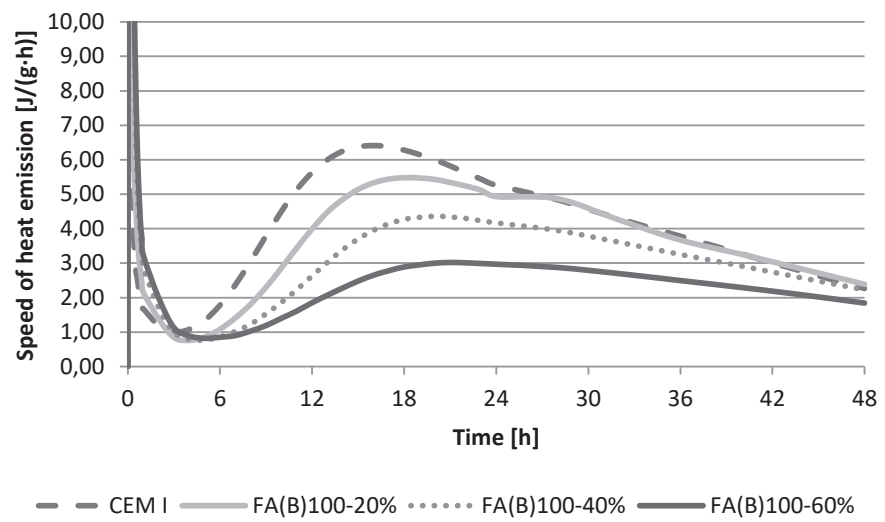

Fig. 1. The influence of biomass fly-ash addition on the calorimetric measurement results of cement binders

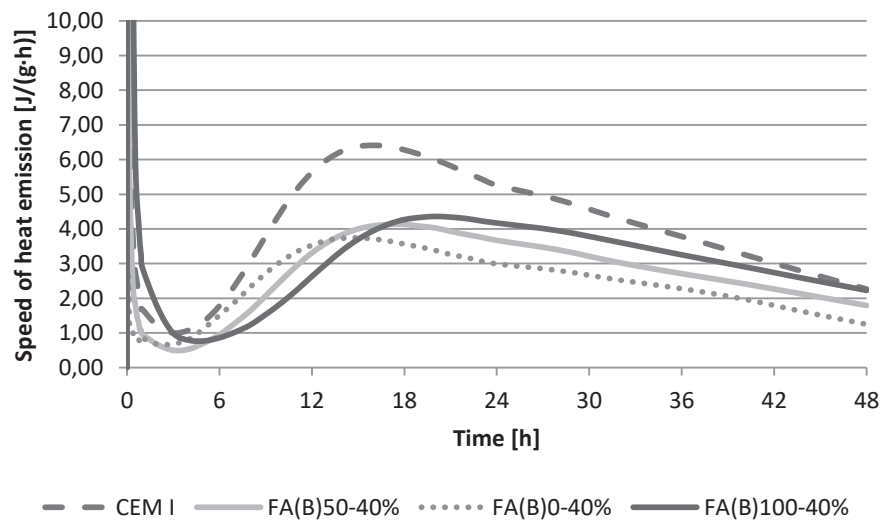

Fig. 2. The influence of $40 \%$ replacement of cement with biomass fly-ash addition, coal fly-ash addition and the mix of biomass fly-ash and coal fly-ash addition on the calorimetric measurement results of cement binders 


\subsection{Results of the workability tests}

The workability test results of fresh mortar mixes with the addition of biomass and coal fly-ashes are presented in Table 5. The slump test result for the control specimens was $14 \mathrm{~cm}$. To achieve this result coal fly-ash fresh mortar specimens needed an additional $13 \%$ water. The specimens of biomass fly-ash needed $17 \%$ of water in the mixture.

The result are similar to findings reported in the literature. A severe reduction of consistency was reported [22] and results comparable to this $[18,23]$. The researchers attribute the increased water demand of woody biomass fly-ashes to either a higher specific surface of their irregularly-shaped particles or a higher content of unfired carbon. The coal fly-ashes with small percentage of LOI tend to increase workability and have small effect on water demand $[3,8]$.

Table 5. The results of cement mortar workability tests

\begin{tabular}{|c|c|c|c|}
\hline Series code & $\begin{array}{c}\text { Slump test } \\
\text { result }[\mathrm{cm}]\end{array}$ & $\begin{array}{c}\text { Water content in the } \\
\text { mortar mix }[\mathrm{g}]\end{array}$ & $\begin{array}{c}\text { Water content } \\
\text { change [\%] }\end{array}$ \\
\hline CEM I & 14.0 & 225 & 100 \\
\hline FA(B)0-30\% & 13.7 & 255 & 113 \\
\hline FA(B) $100-30 \%$ & 14.5 & 265 & 117 \\
\hline
\end{tabular}

\subsection{Results of the compressive strength tests}

The compressive strength results of concretes with the addition of biomass and coal flyashes after 7, 28, and 90 days of curing are presented in Fig. 3-5.

The addition of coal fly-ash has caused a diminishment in the compressive strength of the concrete with rising dosage. Between 28 and 90 days of curing the compressive strength of control series did not change. The compressive strength of concrete with part

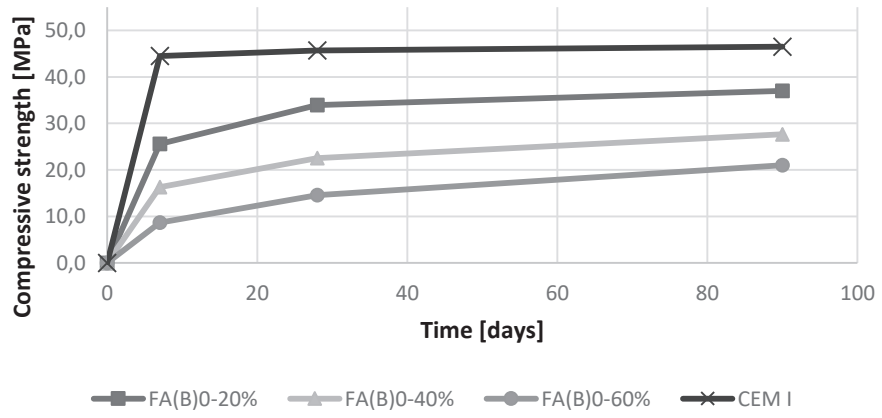

Fig. 3. Effect of coal fly-ash addition on compressive strength of concrete 


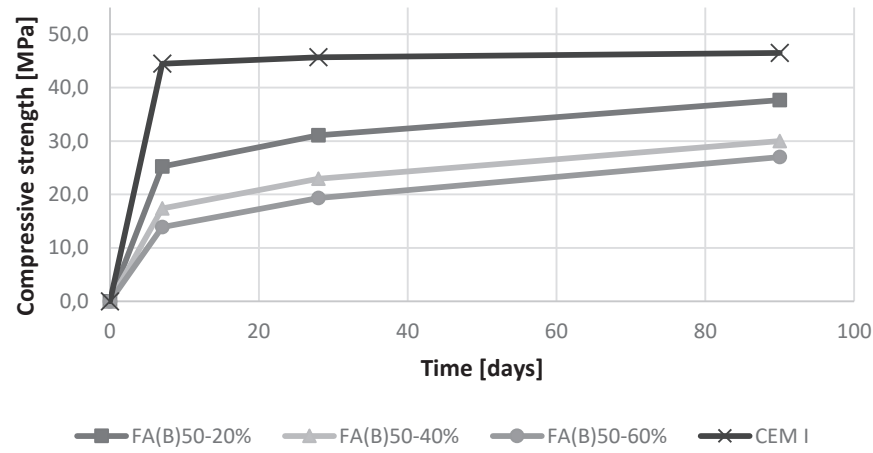

Fig. 4. Effect of coal fly-ash with 50\% replacement with biomass fly-ash addition on compressive strength of concrete

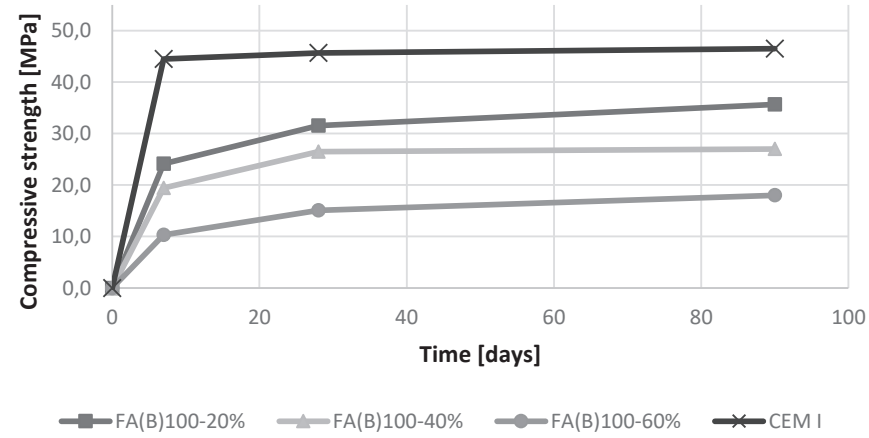

Fig. 5. The effect of biomass fly-ash addition on compressive strength of concrete

of cement replaced by coal fly-ash was significantly higher at 90 day than at 28 day. The 90 day compressive strength of FA(B) $0-60 \%$ specimens was higher by $44,8 \%$ comparing to the series' 28 day results. In a similar manner, the addition of fly-ash with $50 \%$ replacement of biomass fly-ash influenced the development of compressive strength between 28 and 90 day of curing - the compressive strength of FA(B) $50-20 \%$ raised by $21.6 \%$ between those test times (Fig. 4). Comparable results were visible in the series with full-replacement of coal flyash with biomass fly-ash addition (Fig. 5).

The half-replacement and full-replacement of coal fly-ash with biomass fly-ash did not change the compressive strength of the concrete significantly (Fig. 6). The development of compressive strength was similar with the addition of each fly-ash composition.

Coal fly-ash addition generally diminishes the strength of the concrete specimens, especially in its early increase $[3,8]$. This was observed in this study. The compressive strength development of biomass fly-ashes specimens was similar. Also an additional gain in the compressive strength of coal fly-ash and biomass fly-ash can be seen between 28 and 90 days after casting. This may suggest the influence of a pozzolanic reaction from both fly-ashes. In 


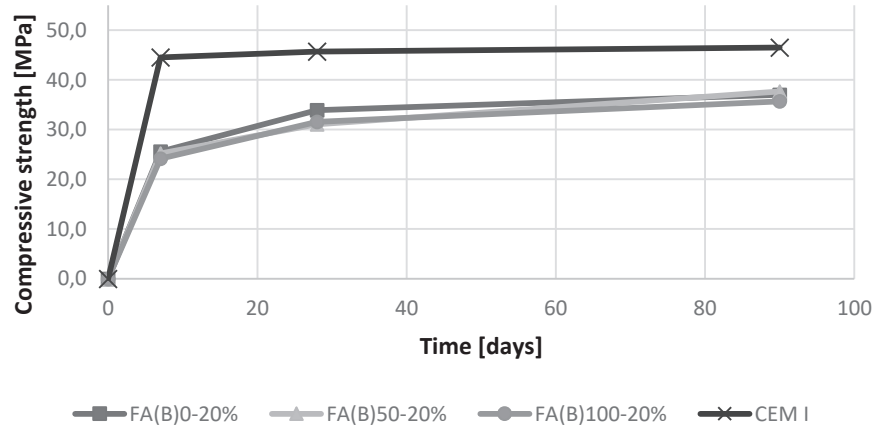

Fig. 6. The effect of $20 \%$ cement replacement with coal fly-ash addition, mixed coal and biomass flyash addition, and biomass fly-ash addition on compressive strength of concrete

other research the difference between 28 day and 90 days compressive strength of composites with the addition of woody biomass fly-ashes was not reported [18]. A comparable $6 \%$ gain of compressive strength of sawdust biomass fly-ash cement concrete was reported [22].

\subsection{Results of the abrasion tests}

The abrasion tests results for concretes with the addition of fly-ashes are presented in Figure 7. The 20\% replacement of cement with either coal, mixed coal and biomass, or biomass fly ash did not influence the abrasion results. The replacement of $40 \%$ or $60 \%$ cement with coal fly-ash reduced the abrasion resistance by about $40 \%$. The replacement of coal flyash with biomass fly-ash resulted in a smaller loss due to abrasion. The full-replacement of coal fly-ash with biomass fly-ash has resulted in a $24 \%$ reduction in abrasion loss of volume.

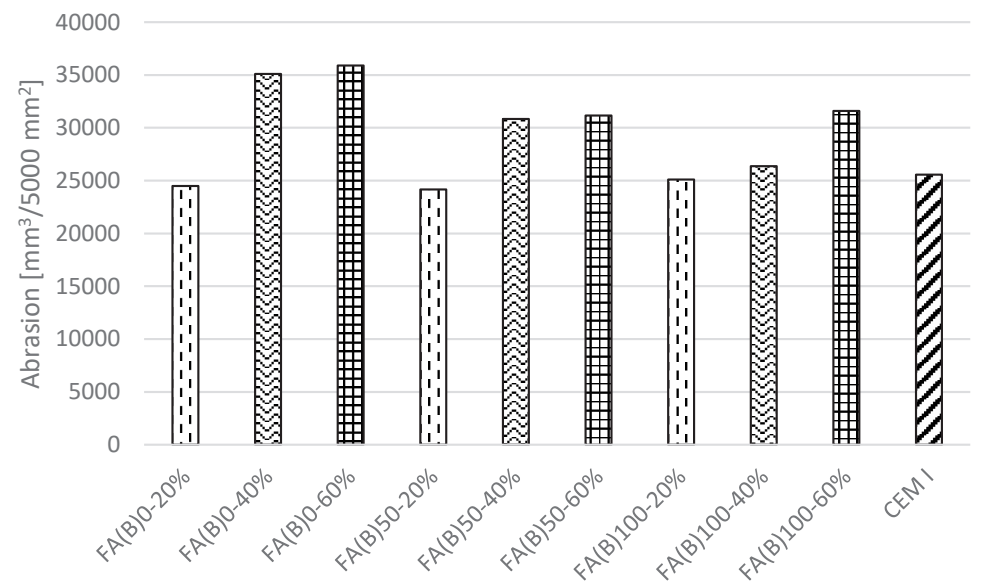

Fig. 7. The effect of cement replacement with coal fly-ash addition, mixed coal and biomass fly-ash addition, and biomass fly-ash addition on abrasion test results 


\subsection{Results of density and water absorption tests}

According to [20] tests on cement mortar with and without $15 \%$ replacement of cement with wood waste fly-ash have shown little effect on water absorption. In another study [27] the increase of wood waste fly-ash from 5\% to $30 \%$ of binder mass in cement concrete resulted in a less than $1 \%$ increase in water absorption. The increase in dosage of woody biomass flyash in this study also marginally influenced this property, but the difference between water absorption measured on control specimens and fly-ash specimens was significantly greater.

The water absorption and density test results are presented in Table 6. All the series with cement replaced partly by the fly-ashes were characterized by higher water absorption compared to control specimens. Slightly lower water absorption results were measured on biomass fly-ash concretes. A significant difference between densities of specimens with an addition of fly-ash and control specimens was not observed.

Table 6. The results of density and water absorption tests

\begin{tabular}{|c|c|c|}
\hline & Water absorption [\%] & Density $\left[\mathrm{g} / \mathrm{cm}^{3}\right]$ \\
\hline FA(B)0-20\% & 7.22 & \\
\hline FA(B)0-40\% & 8.18 & 2.16 \\
\hline FA(B)0-60\% & 8.52 & 2.10 \\
\hline FA(B)50-20\% & 7.19 & 2.07 \\
\hline FA(B) $50-40 \%$ & 7.60 & 2.18 \\
\hline FA(B)50-60\% & 7.09 & 2.15 \\
\hline FA(B) $100-20 \%$ & 6.90 & 2.14 \\
\hline FA(B) $100-40 \%$ & 7.11 & 2.19 \\
\hline FA(B) $100-60 \%$ & 7.36 & 2.19 \\
\hline CEM I & 4.84 & 2.16 \\
\hline
\end{tabular}

\section{Conclusions}

The analysis of the test results shows that the influence of biomass fly-ash and coal flyash on cement concrete and cement binder can be similar. The addition of biomass fly-ash resulted in a slightly bigger peak of hydration. This could be attributed to the larger specific surface of biomass fly-ash or its chemical composition. The development of compressive strength was similar comparing specimens with the addition of coal fly-ash and biomass flyash. This may suggest that the hydration and pozzolanic capabilities of both types of blended binders were similar. The addition of biomass fly-ash resulted in a similar or up to $24 \%$ better abrasion resistance compared to concrete specimens with the addition of coal fly-ash. There 
were no significant differences between the influences of the addition of biomass fly-ash and coal fly-ash considering the density and water absorption of concrete.

This study has shown that it is possible to produce concrete with an addition of biomass fly-ash that has similar properties to concrete with an addition of coal fly-ash. Biomass flyashes vary in chemical composition. Even different batches of fly-ash from the same source may present different levels of contained oxides. The issue of elevated LOI percentage can be sufficiently addressed by modern technical means in power plants or fly-ash treatment. Electrostatic separation of positively charged coal particles from negatively charged minerals can downsize the LOI percentage of treated fly-ashes below 5\%. The separated coal particles can be reused in the burning chamber [28]. It is tremendously important to check biomass fly-ashes before adding it to cement composites mixes to maintain their utility. For a better understanding of the results, more chemical analysis of fly-ashes ought to be performed. Moreover, for a better assessment of the biomass fly-ash cement composite utility, more studies should be performed. In particular, there is a lack of sufficient knowledge on the durability of such composites.

Studies have been carried out in the framework of work no. MB/WBiIŚ/8/2016 and work no. S/WBiIŚ/1/2016 financed from the funds for science from Ministry of Science and Higher Education.

\section{References}

[1] Rocznik statystyczny przemystu 2015, eds. Witkowski J., Dmochowska H., Główny Urząd Statystyczny, Warszawa 2015, 119-442.

[2] BP Statistical Review of World Energy, eds. Dale S. British Petroleum, London 2016.

[3] Giergiczny Z., Popiót lotny w składzie cementu i betonu - monografia, Wydawnictwo Politechniki Śląskie, Gliwice 2013.

[4] Ministerstwo Gospodarki, Projekt Polityki energetycznej Polski do 2050 roku, Warszawa 2015.

[5] Uliasz-Bocheńczyk A., Mokrzycki E., Biomasa jako paliwo w energetyce, Rocznik Ochrona Środowiska, Vol. 17, 2015, 900-913.

[6] Ahmaruzzaman M., A review on the utilization offly ash, Progress in Energy and Combustion Science, Vol. 36, 327-363.

[7] Baran T., Ostrowski M., Giergiczny Z., Wykorzystanie mieszanych popiołów lotnych $z$ oddzielnego spalania pytu węglowego i paliw wtórnych $w$ produkcji spoiw wiążacych, Materiały Budowlane, Vol. 12, 2015, 37-40.

[8] Giergiczny Z., Wtaściwości popiołu lotnego a trwałość betonu, Budownictwo Technologie Architektura, Vol. 39, 2007, 44-48.

[9] Cuenca J., Rodriguez J., Martín-Morales M., Sánchez-Roldán Z., Zamorano M., Effects of olive residue biomass fly ash as filler in self-compacting concrete, Construction and Building Materials, Vol. 40, 2013, 702-709. 
[10] Lessard J.-M., Omran A., Tagnit-Hamou A., Gagne R., Feasibility of using biomass fly and bottom ashes in dry-cast concrete production, Construction and Building Materials, Vol. 132, 2017, 565-577.

[11] Gawlicki M., Graur Z., Ślęzak E., Popioły lotne ze spalania biomasy jako składniki spoiw drogowych, Scientific Works of Institute of Ceramics and Building Materials, Vol. 19, 2014, 34-46.

[12] Madandoust R. Ranjbar M.M., Maghadam H.A., Mousavi S.Y., Mechanical properties and durability assessment of rice husk ash concrete, Biosystems Engineering, Vol. 110, 144-152.

[13] Sua-Iam G., Makul N., Utilization of coal- and biomass-fired ash in the production of selfconsolidating concrete: a literature review, Journal of Cleaner Production, Vol. 100, 2015, 59-76.

[14] Rodriguez de Sensale G., Strength development of concrete with rice-husk ash, Cement and Concrete Composites, Vol. 28, 2006, 158-160.

[15] Jamil M., Khan M.N.N., Karim M.R., Kaish A.B.M.A., Zain M.F.M., Physical and chemical contributions of Rice Husk Ash on the properties of mortar, Construction and Building Materials, Vol. 128, 2016, 185-198.

[16] Khalil N.M., Hassan E.M., Shakdofa M.M.E., Farahat M., Beneficiation of the huge waste quantities of barley and rice husks as well as coal fly ashes as additives for Portland cement, Journal of Industrial and Engineering Chemistry, Vol. 20, 2014, 2998-3008.

[17] Cheah C.B., Ramli M., The implementation of wood waste ash as a partial cement replacement material in the production of structural grade concrete and mortar: An overview, Resources, Conservation and Recycling, Vol. 55, 2011, 669-685.

[18] Wang S., Miller A., Llamazos E., Fonseca F., Baxter L., Biomass fly ash in concrete: Mixture proportioning and mechanical properties, Fuel, Vol. 87, 2008, 365-371.

[19] Rajamma R., Ball R.J., Tarelho L.A.C., Allen G.C., Labrincha J.A., Ferreira V.M., Characterisation and use of biomass fly ash in cement-based materials, Journal of Hazardous Materials, Vol. 172, 2009, 1049-1060.

[20] Elinwa A.U., Ejeh S.P., Effects of incorporation of sawdust incineration fly ash in cement pastes and mortars, Journal of Asian Architecture and Building Engineering, Vol. 3, 2004, 1-7.

[21] Abdullahi M., Characteristics of wood ash/OPC concrete, Leonardo Electronic Journal of Practices and Technologies, Vol. 8, 2006, 9-16.

[22] Demonstration of manufacturing technology for concrete and CLSM utilizing wood ash from Wisconsin, eds. Naik T.R., Kraus R.N., Siddique R., Department of Civil Engineering and Mechanics, University of Wisconsin-Milwaukee, Milwaukee 2002.

[23] Elinwa A.U., Mahmood Y.A., Ash from timber waste as cement replacement material, Cement \& Concrete Composites, Vol. 24, 2002, 219-222.

[24] Berra M., Mangialardi T., Paolini A.E., Reuse of woody biomass fly ash in cement-based materials, Construction Building Materials, Vol. 76, 2015, 286-296.

[25] Elinwa A.U., Ejeh S.P., Mamuda A.M., Assessing of the fresh concrete properties of selfcompacting concrete containing sawdust ash, Construction Building Materials, Vol. 22, 2008, 1178-1182. 
[26] Zielenkiewicz W., Kamiński M., A conduction calorimeter for measuring the heat of cement hydration in the initial hydration period, Journal of Thermal Analysis and Calorimetry, Vol. 65, 2001, 335-340.

[27] Udoeyo F.F., Inyang H., Young D.T., Oparadu E.E., Potential of wood waste ash as an additive in concrete, Journal of Materials in Civil Engineering, Vol. 18, 2006, 605-611.

[28] Bittner J.D., Gąsiorowski S.A., Separacja popiołów lotnych i usuwanie amoniaku w Tampa Electric Big Bend, International Conference EuroCoalAsh, Warsaw, 6-8 October 2008. 